\title{
New Holistic Strategy of Sustainable Rural Development Management-Experience from Indonesia: A PESTEL-SOAR Analysis
}

\author{
Muhardi Muhardi ${ }^{1}$, Ade Y. Mafruhat ${ }^{*}$, Cici Cintyawati ${ }^{1}$, Tatty A. Ramli², Rohafiz Sabar ${ }^{3}$, Hartini Ahmad ${ }^{3}$, Sarah $^{2}$ \\ Shaharruddin $^{3}$, Abdul M. Bohari ${ }^{3}$ \\ ${ }^{1}$ Faculty of Economic and Business, Universitas Islam Bandung, Bandung 40116, West Java, Indonesia \\ ${ }^{2}$ Faculty of Law, Universitas Islam Bandung, Bandung 40116, West Java, Indonesia \\ ${ }^{3}$ School of Technology Management and Logistics, Universiti Utara Malaysia, Sintok 06010, Kedah Darul Aman, Malaysia
}

Corresponding Author Email: ade.yunita.mafruhat@unisba.ac.id

https://doi.org/10.18280/ijsdp.150707

Received: 30 June 2020

Accepted: 26 September 2020

\section{Keywords:}

sustainable rural development management, holistic strategy, village head leadership

\begin{abstract}
This article offers a new strategy of holistic rural development by utilizing the externa strengths of the rural and the internal strength based on the experience of one of the rural in Indonesia that has been succeeded in turning the rural from the poorest into the best in the national rank. The successful formula is associated with the role of village leaders in benefiting opportunities from the existing external-internal aspects. To capture more holistic development phenomena including political, economic, social, technological, environmental and legal phenomena while generating new bottom-up strategies, the study uses PESTEL and SOAR analysis. This study found that the first condition for rural development in Indonesia is the development of village leadership management strength in holistically managing the potential and opportunities of external and internal villages. It changes the fundamental paradigm that holistic rural development must be seen as a whole (the village can take advantage of the existing external-internal strengths) partially (the village only focuses on utilizing the village's internal strength utilization agricultural potential). Through the PESTELs-SOAR analysis approach, the strategy offered becomes more rational and comprehensive in sustainable rural development by collaborating the village bottom-up strategy approach while still considering prevailing external conditions (more top-down).
\end{abstract}

\section{INTRODUCTION}

The main issues of rural development in developing countries are poverty, livelihoods, and the environment [1]. Therefore, Todaro and Smith [2] mentioned the importance of rural development, especially in developing countries since their source of poverty comes from villages. Indonesia, for example, during the period of 1970-2019, the number of sources of rural poverty was linked to livelihoods and the provision of limited employment in the village. In the HarordDomar Model, it is explained that the limited employment in the village due to the economy that only relies on the traditional-agricultural sector which causes a surplus of labor. This surplus of labor later became one of the causes of the high rate of migration from rural to urban areas. If it is not matched by the availability of jobs, the surplus of labor from the village will actually increase the level of poverty in urban areas. These problems then occur in many developing countries including Indonesia. Based on data from the Indonesian Central Statistics Agency [3], Indonesia's urban poverty over the past 44 years (1970-2014) has continued to increase due to the lack of absorption of surplus labor from villages at an average of 0.2 percent per year. Meanwhile, poverty in Indonesian villages in the same period fell by an average of -0.91 percent per year. The decrease in the percentage of rural poverty does not mean that development has occurred in the village, but rather because the rural poor have migrated to the city which causes the continually increasing number of poor people in the city. This condition becomes a major concern of the Indonesian Government. If Indonesia wants to carry out a development, it needs to start from the source of the development problem itself that is the village. The awareness of the importance of village development in Indonesia was also demonstrated by the issuance of Law No. 6 of 2014 concerning Villages. This is an embodiment of 'Nawacita' or the nine priority agendas of Indonesia's president and vice president Jokowi-Jusuf Kalla for the 2014-2019 period.

The third priority agenda states that the Government of Indonesia is committed to developing Indonesia from the periphery and then increasing the village development. Based on this commitment, the village is then given the authority to independently manage its governance with the help of special funds (the Village Fund Program) provided directly by the central government. The Village Fund Program is not only the first in Indonesia, but also the first and the largest in the entire world [4]. Interestingly, through this commitment, village development in Indonesia has become a particular priority. This was demonstrated by the establishment of the Ministry of Villages, the Development of Disadvantaged Regions and Transmigration of the Republic of Indonesia (Ministry of Rural Development) through Presidential Regulation No. $12 / 2015$. The establishment of this new ministry was a new history for Indonesia with its first Minister Abdul Halim Iskandar and Deputy Minister Budi Arie Setiadi. This is a new 
beginning for the development of villages in Indonesia. The history of rural development in Indonesia, it can be seen in Table 1.

Table 1. History of rural development in Indonesia

\begin{tabular}{c}
\hline Component \\
\hline Development of Village \\
Poverty 1970-2014 \\
Development of Urban \\
Poverty 1970-2014 \\
Causes of Urban \\
Poverty > Village \\
Poverty
\end{tabular}

Indonesia's commitment to rural development

Information
Continues to decrease -0.9 percent /
year.
Continue to increase 2.0 percent /
year.

Poor villagers migrate to cities in search of decent work.

The passing of law number 6 of 2014 on villages by the president of the Republic of Indonesia.

Village development is one of the priority agendas of the President of the Republic of Indonesia Jokowi-

Jusuf Kalla for the 2014-2019 period as outlined in the 'Nawacita' document.

There is a special budgetary fund from the Indonesian government for village development called 'Dana Desa'.

The Indonesian Village Fund is the first and largest in the world to support village development.

Establishment of a special ministry for village development.

The formation of a special Ministry to support Village development

'Ministry of Villages, Development of Disadvantaged Areas and

Transmigration of the Republic of Indonesia' (Ministry of Rural

Development) through Presidential Regulation Number 12 of 2015.

The first minister was 'Ministry of Villages, Development of Disadvantaged Areas and

Transmigration of the Republic of Indonesia' namely Abdul Halim

Iskandar and the Deputy Minister namely Budi Arie Setiadi.

Previous research related to village development can be divided into two focus groups: first, research that is still at the level of concepts regarding ideal village development, village development management, and the reasons of why village development are important; second, research related to case studies of the implementation of village/rural development. First, research related to ideal village development, village development management, and the reasons of why village development is important have been carried out by Jenkins [5]; Akgün et al. [6]; Tomashuk [7]; and Koopmans et al. [8]. Second, research related to case studies of the implementation of village development in a country have been done by Courtney et al. [9]; Popescu [10]; and Chen et al. [11]. Based on research that have been done and mentioned above, there is no single research discussed about what holistic strategies can facilitate the implementation of village development so that employment can be created and urbanization process can be occurred. Creating jobs in the village, let alone getting to the stage of urbanization process, is a difficult thing to do. Many literatures stated that village development must involve agricultural potential. As Popescu [10] said, the successful village development is often associated with the successful utilization of village agricultural potential so that the main focus of development is more on the dominance of the role of agricultural sector. The question is, do all villages have agricultural potential? What about villages that have no agricultural potential at all? Is it still possible for them to carry out village development? If so, are the development strategies different? What kind of village development management strategy should be implemented so that each village can maximize its potentials sustainably, either potentials that have been explored and have not been explored?

This article tries to answer these questions based on the experience of one of the villages in Indonesia that initially did not maximize the potential of agriculture and its natural resources. Due to the village's potential that was not fully exploited, it was difficult for the villagers to find jobs, so this rural poverty could not be avoided. Majasari Village became one of the villages that contributed to poverty in Indonesia. This classical problem has caused many of the villagers to migrate to find jobs that are well-paid and made them can go abroad, namely becoming Indonesian Workers. However, in 2016 , this village which was used to be a poor village, was later awarded as the best village in Indonesia for successfully implementing the development. However, in 2016 this previously poor village was awarded the best village in Indonesia for successfully implementing development in its village by optimally utilizing the village's potential. This award's achievement proves Majasari Village can overcome development problems, especially rural poverty. Based on the experience, this article aims to identify what kind of holistic strategy can be formulated to manage sustainable rural development, which is expected to become a development strategy framework that can be followed, especially by other villages in Indonesia and villages in developing countries in general. Thus, this study is important to do, considering that there is no holistic village development framework that utilizes bottom-up and top-down and internal-external conditions in the village.

\section{SUSTAINABLE RURAL DEVELOPMENT MANAGEMENT}

A village has an important role in the economy of a country because it is a major supplier of food raw materials for households and industries [7]. Hence, the successful village/rural development is often associated with the successful utilization of agricultural potential so that the main focus of village development is more on the dominance of the role of agricultural sector [8]. Rural development is considered important to overcome the global food crisis through the development of agricultural sector [10]. Ironically, what happens is that the exploitation of subsistence/semisubsistence agriculture is not matched by good agricultural performance. The causes of poor productivity are the aging factor of rural people, lack of infrastructure, inadequate agricultural credit/financing, and the use of inappropriate production factors that damage the surrounding environmental ecosystem, which ultimately inhibits agricultural production. According to Akgün et al., [6], the actual rural/village development is, indeed, prioritizing the economy, but it should not rule out the environment. In other words, the village development that must be implemented is sustainable village development. Sustainable means the execution of economic 
activities accompanied by environmental preservation, so that the resources used now can be saved for future generations [2]. This view produces the importance of the concept of sustainable village development. This concept prioritizes the ecological economy that is benefiting the environmental potential of the village for the economic interests and vice versa in order to create economic and ecological sustainability of the village simultaneously. Akgün et al. [6] reveal there are 5 reinforcing factors to smooth the implementation of sustainable village development: physical systems, social systems, economic systems, locality systems, and creative systems as shown and described in Figure 1.

Talking about locality is talking about natural capital or ecology. Village ecology is closely related to the rural natural heritage. According to Courtney et al. [9] there are three roles of natural heritage in village development: the core role, the primary role, and the reliant role. These three roles, which is shown and explained in Figure 2, contribute to economic improvement without compromising the surrounding environment.

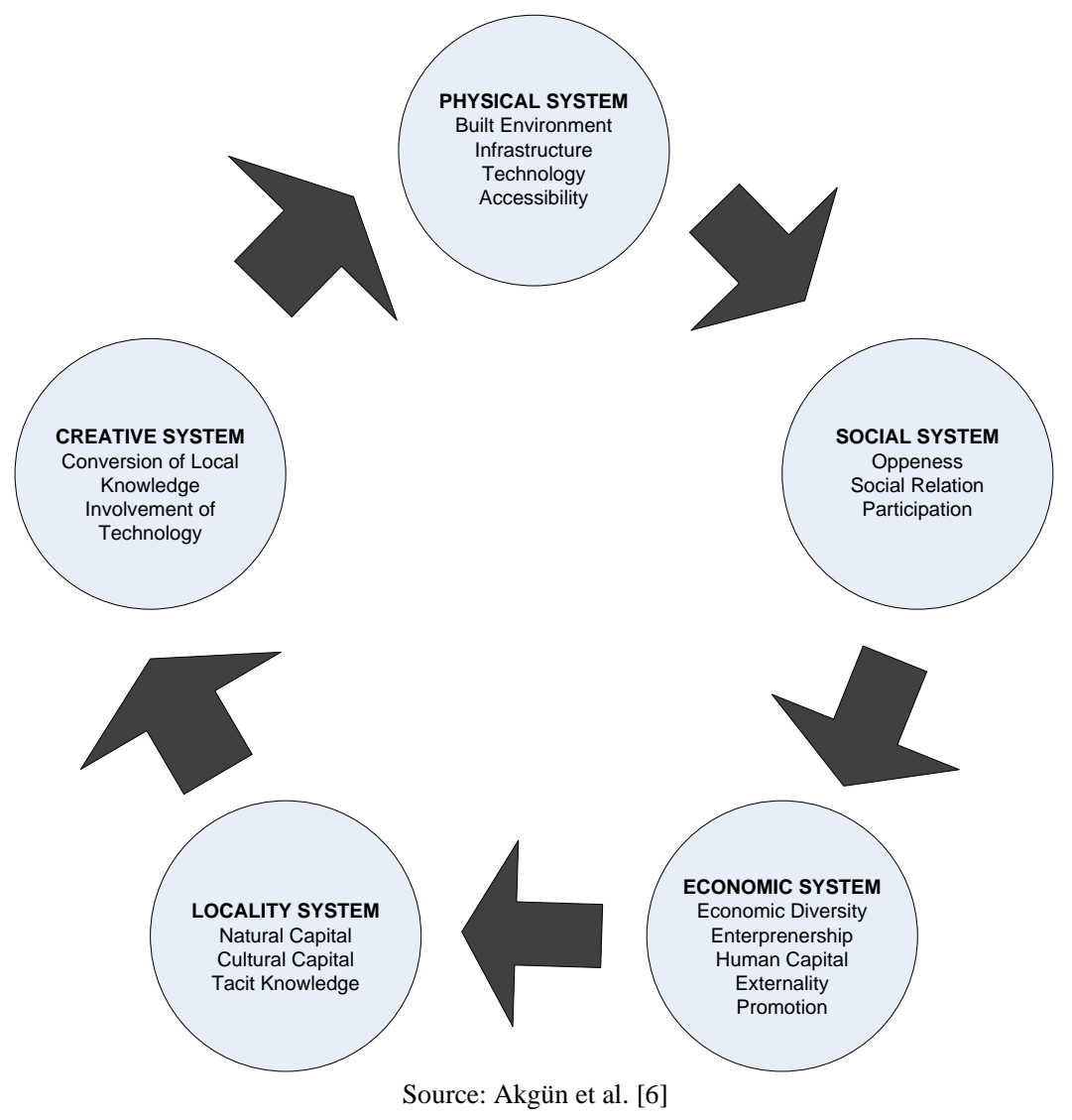

Figure 1. Reinforcing factors for sustainable village development

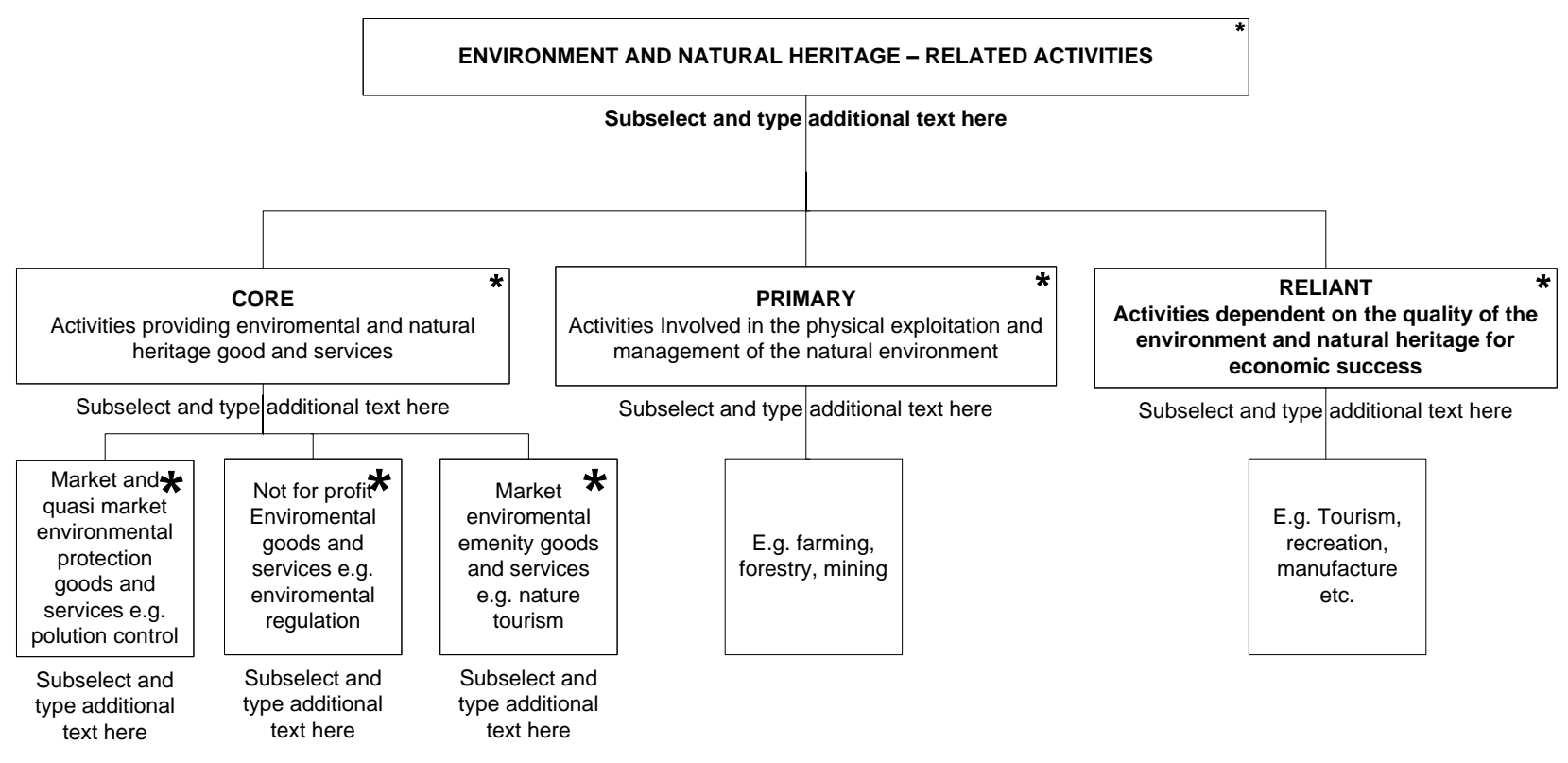

Source: Courtney et al. [9]

Figure 2. The role of rural natural heritage in village/rural development 
Meanwhile, Chen et al. [11] argue that developing rural areas in a sustainable manner needs integration between rural development and urban development. This will allow the transfer of resources to one another which will benefit both parties, so that the village economy that has not been developed can be developed sustainably. Regarding the village economy, Conneely and Mahon [12] state that rural economic development can be carried out only with a good institutional governance system. This good institutional system will do the efforts to create and maintain the added value of village agricultural products, so as to guarantee the village economic sustainability. One of the strengthening factors of institutional governance is the presence of quality certificates. In addition to institutional governance, Koopmans et al. [8] said that rural development will succeed if there is multi-actor governance which will not only magnify the added value but can also increase the legitimacy and policy transparency, empower local communities, and support regional development that reconnects agriculture and rural development. Multi-actor governance can be realized by fulfilling these following six factors: informal networks between interested parties, bottomup initiatives, polycentric decision making, bottom-up initiatives that need to be integrated at various policy levels, the necessity of having a third party as a liaison agent between parties, and trust and transparency between parties. Based on this view, Koopmans et al. [8] formulate five strategies of sustainable village/rural development. First, the strategy that reconnects various village food chain resource actors with formal partnership organizations. Second, the strategy of making use the potential of low-carbon village resources. Third, the strategy of rural economic modernization that is independent and structured. Fourth, the strategy of optimization in the utilization of village land resources. Fifth, the strategy of product innovation development to maintain supply sustainability. Of course, these strategies will be materialized if they are followed by appropriate and righteous management of village development. According to Tomashuk [7], there are principles of village development management that must be complied. First, the use and recognition that natural resources in village economic practices still pay attention to environmental aspects of the rural area. Second, the need of integration between social, political, economic, and environmental elements in village development. Third, the need of cautious attitude towards resource exploitation. Fourth, the necessity to maximize the development for the physical and psychological needs of the village. Fifth, to maximize the production and increase village products. Based on literature review, the sustainable rural development management strategy in Indonesia will fill the void of the review, in which it will provide a clear and applicable picture in the implementation of sustainable village development management, especially for villages that have not maximized their potential yet.

\section{METHODOLOGY}

This research applies a descriptive-qualitative method. Referring to the objectives to be achieved, namely to obtain a comprehensive and applicable strategy related to sustainable village development management, this study uses 2 (two) data sources: primary and secondary data. Primary data are obtained through semi-structured interviews to select study sample. The determination of study sample is done by purposive sampling according to the specified characteristics and results in Majasari Village in Indramayu-Indonesia Regency chosen as the study sample. This village is selected because initially, it was a poor village, but in 2016, it was chosen as the best village in Indonesia. Meanwhile, secondary data is data obtained from previous research studies, villagerelated data obtained from the Indonesian Central Statistics Agency and the Ministry of Villages, Development of Disadvantaged Regions and Transmigration of the Republic of Indonesia. For more details regarding the information on primary data and secondary data obtained in this study, see Table 2.

Table 2. Information related to primary and secondary data

\begin{tabular}{ccc}
\hline Location & Primary data & Secondary Data \\
\hline Majasari Village- & $\begin{array}{c}\text { Indramay Regency-West } \\
\text { Java Province-Indonesia }\end{array}$ & Indonesia \\
Source & $\begin{array}{c}\text { Direct interviews with the } \\
\text { village head and his staff }\end{array}$ & $\begin{array}{c}\text { Statistics, Ministry of } \\
\text { Migration and } \\
\text { Disadvantaged } \\
\text { Villages, previous } \\
\text { studies. }\end{array}$ \\
Nature & $\begin{array}{c}\text { Data obtained directly } \\
\text { from the source }\end{array}$ & $\begin{array}{c}\text { Data obtained from } \\
\text { government literature } \\
\text { and websites }\end{array}$ \\
$\begin{array}{c}\text { Search } \\
\text { Time }\end{array}$ & 2019-2020 & 2019-2020 \\
\hline
\end{tabular}

This research refers to the concept of sustainable village development. According to the literature, village development is called sustainable if the village's socio-economic activities are carried out while paying attention to the village environment. To get the results that can be accounted for, this research used the PESTELs analysis approach (Political, Economic, Social, Technological, Legal, and Environment) combined with SOAR analysis (Strength, Opportunities, Aspiration, Results). The PESTELs analysis approach was chosen because it was able to capture external opportunities for rural development as a whole, including political, economic, social, technological, legal, and environmental aspects so that the strategy created could represent a top-down strategic approach. Meanwhile, the SOAR analysis approach was chosen because it was able to capture the village community's desires and expectations so that the strategy created represented a bottom-up strategy approach. These two approaches are expected to produce a formulation of sustainable village development management strategies that truly integrate all aspects and are in accordance with village conditions so that the strategies are comprehensive (bottom up and top-down).

\section{RESULT AND DISCUSSION}

This section is part of the results and discussion of PESTELs analysis and SOAR analysis. This section is divided into 3 (three) sections; first, PESTELs analysis; Second, SOAR analysis; Third, discussion in formulating a holistic strategy for sustainable village development. The first part, PESTELs analysis, focuses on identifying external opportunities utilized by Majasari Village in its village development process. This external identification was obtained from secondary data, which was later confirmed by 
the Majasari Village government through interviews, whether secondary data includes opportunities or threats to village development. Secondary data that are confirmed are top-down policies and regulations. The opportunities identified from this PESTELs analysis results become a component of opportunities in the SOAR analysis. The second part, SOAR analysis focuses on positive internal identification, which includes four components; Majasari Village strength; the aspirations of the people of Majasari Village; external opportunities for the Development of Majasari Village obtained from PESTELs Analysis; and the final goal to be achieved by Majasari Village. Primary data for the three components of SOARs analysis, namely strength, aspiration, and results, are bottom-up data because they are the natural desires and aspirations of the people of Majasari Village. The results of the PESTELs and SOAR analysis are then discussed in part three, namely the discussion section to formulate a holistic strategy for sustainable village development.

Table 3. Political factors, effects, and opportunities/challenges of rural development in Indonesia

\section{Political Factor}

1. President's leadership and policy direction towards the village

2. Regulations related to village development from the Indonesian government, particularly from the Ministry of Villages, Disadvantaged Regions and Transmigration

3. There is a development program of transmigration area from the Ministry of Villages, the Development of Disadvantaged Regions and Transmigration

4. The determination of Village Development Index as a measurement of village development in Indonesia

5. The determination of three major programs to build the villages, namely the Wiradesa Community Network (JKWD), the Village Economic Granary (LED), and the Village Cultural Circle (LBD)

6. The amount of the village fund/budget set

7. Cooperation between the Ministry of Villages, the Development of Disadvantaged Regions and Transmigration with the Ministry of Energy and Mineral Resources (ESDM) to build power plants for rural areas

8. The direction of village development according to the 20152019 RPJMD (Regional Medium-Term Development Plan)

9. A village map is created to assist the village development in line with the characteristics of villages in Indonesia in 2016

10. Citizenship awareness of the villagers

11. The Ministry of Villages, Disadvantaged Regions and Transmigration collaborates with SETARA institute for Democracy and Peace and the Indonesian Paralegal Network (JPI) to produce research-based village development policies

12. The position of Developing Villages Index (IDM) of a village

13. The village head leadership in working with external parties (sub-district, district, and provincial governments)

\section{Effects on the Village}

The position of village in Indonesia has become clear that it has its own authority and function in the rural development

Majasari Village has a direct budget/fund from the central government

\section{Opportunities/Challenges}

1. A clear position of a village politically. The village governments feel free to build their villages independently

2. Many villages have not been able to benefit the potential of their villages, so that the budget provided by the government is wasted since it is not maximally absorbed

3. Strong leadership of the village head is a major potential in implementing village development in Indonesia

\subsection{PESTELs analysis}

PESTELs Analysis is based on the results of interviews and secondary data obtained. More details on the results of PESTELs analysis of each factor are explained below:

\subsubsection{Political factors}

The result shows that the Indonesian government support rural area development and is strongly committed to carrying out large-scale village development (Table 3). This commitment is demonstrated by the issuance of Law No. 6 of 2014 concerning Villages. In addition, all villages are also a priority program of the Indonesian government. This is reflected in 'Nawacita' number 3 (three). Surely, this has a positive impact on village authority and functions. Since the issuance of this commitment, villages throughout Indonesia have their own authority and functions to manage their respective villages. Management funds are also given directly by the Indonesian government.

\subsubsection{Economic factors}

The identification results show there are 4 (four) economic factors that determine the implementation of rural development in Indonesia (Table 4). World economic conditions that affects the Indonesian economic condition is decisive for the smooth implementation of development in Indonesia. This is because the condition of Indonesian economy -whether it is good or bad-greatly influences the government's proportion on the village budget. Limited budget from the government puts pressure on villages in implementing village development; it is because the funds provided depend on the performance of the development carried out in the village.

Table 4. Economic factors, effects, and opportunities/challenges of rural development in Indonesia

\section{Economic Factor}

1. The economic conditions of the world and Indonesia, such as gross domestic product, economic growth, balance of payments

2. The performance of village-owned companies

3. The ability of the village to produce entrepreneurs

4. The ability of the village to utilize and maximize the resource potential

\section{Effects on the Village}

1. Villages are required to continue to innovate to improve their economic performance.

2. Majasari Village was able to innovate in agricultural sector by transforming various value-added agricultural products using village capital funds and independent funds from joint ventures of the village community who work abroad.

\section{Opportunities/Challenges}

1. The low economic performance of the village caused by the limited knowledge of human resources in utilizing the village potentials

\subsubsection{Social factors}

Social factors being identified are related to mental factors and attitudes of human resources in the village regarding locality (Table 5). The non-optimal utilization of village economic potential is due to the faults of the villagers' way of thinking, where they still view urban area as a far better place than rural area. This is the perspective that made them unaware and ignoring their villages' potential. 
Table 5. Social factors, effects, and opportunities/challenges of rural development in Indonesia

\section{Economic Factor}

1. The low awareness of rural community towards health

2. Rural community have a low level of education

3. Rural community's religion and beliefs

4. The low awareness of rural community to appreciate and uphold local culture

5. Low awareness of rural community to the perception that rural income is better than urban income

6. Rural communities' lifestyle that are less concerned about the health and environment

7. The high or low of the senses of mutual cooperation among rural communities

8. The high or low of the sense of belonging of rural communities toward their villages

9. The attitudes toward 'green' products or ecology

10. Attitudes toward and supporting renewable energy

11. Immigration population growth rates and immigration rate

12. Distribution of age and life expectancy

13. Gender distribution

14. The average of disposable income level

15. Social Class

16. Size and structure of the family

\section{Effects on the Village}

1. Villages are required to continue to innovate to improve their economic performance.

2. Majasari Village was able to innovate in agricultural sector by transforming various value-added agricultural products using village capital funds and independent funds from joint ventures of the village community who work abroad.

\section{Opportunities/Challenges}

The low economic performance of the village caused by the limited knowledge of human resources in utilizing the village potentials

\subsubsection{Technological factors}

The identification result shows that technological factors that can facilitate the implementation of rural development are technology in providing facilities and infrastructure in the village (Table 6).

Table 6. Technological factors, effects, and opportunities/challenges of rural development in Indonesia

\section{Technological Factor}

1. Level of basic infrastructure

2. The rate of technological change

3. The existence of research and technological incentives

4. Technology legislation

5. The level of technology in rural areas

6. Communication infrastructure

7. Access to the newest technology

8. Internet infrastructure and penetration

\section{Effects on the Village}

If all the technological factors are available in the village, it will be easier to carry out village development. This is because the support of technology can facilitate the communication among development actors. Majasari Village has already had good internet access and even has the CCTV.

\section{Opportunities/Challenges}

The existence of communication technology infrastructure facilitates the communication of village development actors with the outsiders

\subsubsection{Environmental factors}

The environment referred to in the context of this study is the ecological environment, not the supporting business environment as in the most of PESTELs analysts (Table 7). It is because this research is related to the term 'sustainable' where sustainability here speaks of the environment-ecology. The decisive environmental factors that can facilitate the implementation of village development are related to the attitudes and mentality of rural communities towards their surrounding environment.

Table 7. Environmental factors, effects, and opportunities/challenges of rural development in Indonesia

\section{Enviromental Factor}

1. Weather associated with climate change

2. The awareness of rural community related to the importance of environmental sustainability

3. The awareness of rural community to recycle the waste

4. 'Rubbish'/waste management

5. The attitudes toward 'green' products or ecology

\section{Effects on the Village}

The government's urge to protect the environment forced the village to protect the surrounding environment. Majasari Village has already had its own waste management

\section{Opportunities/Challenges}

There are still many villages in Indonesia that have no concern about the environment, which is indicated by the lack of handling the waste. There are many residents who still use fertilizers that are less environmentally friendly. The high use of fertilizers is due to the lack of knowledge of citizens related to organic fertilizer; where and how to get it.

\subsubsection{Legislative factors}

The legislative factor related to village development in Indonesia is quite comprehensive since political basis of village development that has formed is already strong (Table 8).

Table 8. Legislative factors, effects, and opportunities/challenges of rural development in Indonesia

\section{Legislative Factor}

1. Law No 6 of 2014 on Village

2. PP No 43 of 2014 concerning regulation for implementing Law No 6 of 2014 on Village

3. PP No 60 of 2014 on Village Fund Sourced from State Budget (APBN)

4. Minister of Home Affairs Regulation No 113 of 2014 on Village Fund Management

5. Minister of Home Affairs Regulation No 37 of 2007 on Guidance on Village Fund Management

6. Presidential Regulation No 2 of 2015 on Development Plan (RPJMN) Year 2015-2019 Village Development and Rural Development

7. Regulation of The Minister of Villages, Development of Disadvantage Regions and Transmigration No 4 and No 5 of 2015 on Village-owned Companies (BUM-Desa) and Priorities for the Use of Village Fund

\section{Effects on the Village}

1. The village is more confident to carry out development because of its clear function and position

2. Majasari Village is able to carry out village development by utilizing village funds provided by the Indonesian government

\section{Opportunities/Challenges}

1. Villages can accelerate the implementation of development by utilizing village funds obtained

2. The low quality of village human resources as development actors in the village, which can ultimately hamper the development itself 
Based on the PESTELs analysis results, it can be said that only social factors have not supported the sustainable village development process in Indonesia. The social factors in question are related to the mental and attitude of human resources in the village. Based on the interview results, it turns out that there are still many village human resources who have low education so that their skills and mentality are low. As a result, the perspective is very limited. Many rural people think that cities' jobs are more feasible than in villages without any eagerness to create innovations to develop their villages. Meanwhile, the other five factors have supported the sustainable village development process.

\subsection{SOAR analysis}

SOAR Analysis is based on interviews and secondary data obtained. It is divided into two groups of components: first, the components that describe the current village conditions consist of Strength Components and Opportunities Components; second, components that describe the desires/hopes of the village in the future consist of Aspirations Components and Result Components. In contrast to SWOT Analysis, SOAR Analysis focuses on analyzing the positive components of the village in the formulation of effective strategies. The following is a more detailed explanation of the results of analysis of each factor in SOAR.

\subsubsection{Strength Component dan Opportunities Component}

Specifically for Opportunities Components, it is created from the extraction of the results of opportunities that can emerged from the results of the PESTELs analysis. Meanwhile, the Strength Component is obtained from interviews with the village community. A clearer description of the strength components and opportunities for village development can be seen in Table 9.

Table 9. Strength component and opportunities component

\section{Strength Component}

1. The cooperation of village government both vertically and horizontally with the governments and partners

2. Strong leadership of the head of the village

3. Strong sense of cooperation and mutual cooperation of the village communities

4. Village planning that has been through deep consideration as indicated by the existence of plan documents

5. The improved awareness of village community

6. Waste treatment is available

7. The establishment of village own-companies

\section{Opportunities Component}

1. The clear political position of the village that made the village government feel free to build the village independently

2. The increased knowledge and technology, so that the transformation of agricultural products in the village can be improved continually

3. The massive technology developments in the era of industrial revolution in various sectors including education requires the village to be more competitive and keep up with the development

4. Ongoing calls for environment protection both domestically and abroad that successfully attract environmental partners in the implementation of rural development

\subsubsection{Aspirations component and result component}

Components of aspirations and outcomes are pictures of the hopes and ideals of the villagers being interviewed. Based on the results of interviews, aspirations and results of village development can be seen in Table 10.

Based on the results of the analysis of PESTELs and SOAR previously explained, the researcher can draw four specific strategies of village development: first, a strategy that utilizes village power to realize the aspirations of the whole village community (Strength-Aspirations Strategy); second, a strategy that utilizes village strengths to realize the village mission and vision (Strength-Results Strategy); third, a strategy that takes advantage the existing opportunities to realize the aspirations of all rural communities (Opportunities-Aspiration Strategy); fourth, a strategy that utilizes the existing opportunities to realize the vision and mission of the village (Opportunities Results Strategy). A clearer description of the four strategies can be seen in Table 11 .

Table 10. Aspirations component and result component

\section{Aspirations Component}

1. The preservation of village locality

2. The creation of jobs/employment in the village

3. The preservation of the culture of cooperation and mutual cooperation

4. The improved Village Development Index

5. The optimization of village company

6. An increase knowledge of rural community

\section{Result Component}

1. Capable of maintaining the status of village development to become an independent and sustainable village

2. The creation of productive, creative, and innovative village human resources

3. Becoming a village exemplary in the implementation of sustainable village/rural development both domestically and abroad

According to Tomashuk [7], the primary condition for the success of a sustainable village development strategy is the quality of human resources who manage the development. This is proven by the success of Majasari Village in developing the village through the leadership of the village head. The strong leadership of this village head then formed the social system referred to by Akgün et al. [6]. The social system in Majasari Village was reflected in the social relations, openness, and participation of the village community that had been successfully built by the village head to develop Majasari Village together. This power of leadership also succeeded in making the village network vertically with the Indonesian government, and horizontally with the village partner. Based on the principles of village development management as stated by Tomashuk [7], Desa/village of Majasari had fulfilled those principles. But what is new is the implementation of the principles of sustainable village development management which emphasizes the leadership role of the village head combined with a sustainable village development strategy. This is an appropriate and new combination in the management of sustainable village development and is based on the real experience of successful rural development in Indonesia. It should be noted that this power of leadership was able to encourage creativity in optimizing village potential by cooperating with human resources who had left the village to contribute some of their income to help run the business or other positive yet benefiting activities in the village (Figure 3). 
Table 11. Strategies of sustainable rural development

\begin{tabular}{cll}
\hline Strategy & Result \\
\hline 1. & $\begin{array}{l}\text { The village government creates programs to strengthen village locality in an attractive and scheduled manner by } \\
\text { involving experts and assisted by the government (in this case, the Ministry of Village, the Development of } \\
\text { Disadvantaged Regions and Transmigration) } \\
\text { The formation of a professional marketing team to create market networks, especially supply chains and product } \\
\text { branding both local and international, in collaboration with the Ministry of Village, the Development of } \\
\text { Disadvantaged Regions and Transmigration and the Ministry of Trade } \\
\text { The socialization accompanied by practice and the provision of tools for the implementation of environmental } \\
\text { preservation programs, in collaboration with environmental experts and the Ministry of Village, the Development } \\
\text { of Disadvantaged Regions and Transmigration }\end{array}$ \\
\hline $\begin{array}{c}\text { Strength-Results } \\
\text { Strategy }\end{array}$ & 1. & $\begin{array}{l}\text { The government made a blue print of the independent village as a guideline for both maintaining the status of } \\
\text { well-developed villages and improving the poor villages, so that all program carried out remain focused and } \\
\text { overseen }\end{array}$ \\
$\begin{array}{c}\text { Opportunities- } \\
\text { Aspiration Strategy }\end{array}$ & 2. & $\begin{array}{l}\text { The need to implement a digital-based village community development and empowerment while still paying } \\
\text { attention to village locality } \\
\text { The need of abroad promotion for village products through the formation of an official marketing team by the } \\
\text { government } \\
\text { Massive socialization and briefings regarding the importance of village locality in sustainable village } \\
\text { development }\end{array}$ \\
\hline $\begin{array}{l}\text { Opportunities-Result } \\
\text { Strategy }\end{array}$ & $\begin{array}{l}\text { The central government is seriously making and socializing smart village guidance documents to integrate social- } \\
\text { economy-technology and environment in sustainable village development }\end{array}$
\end{tabular}

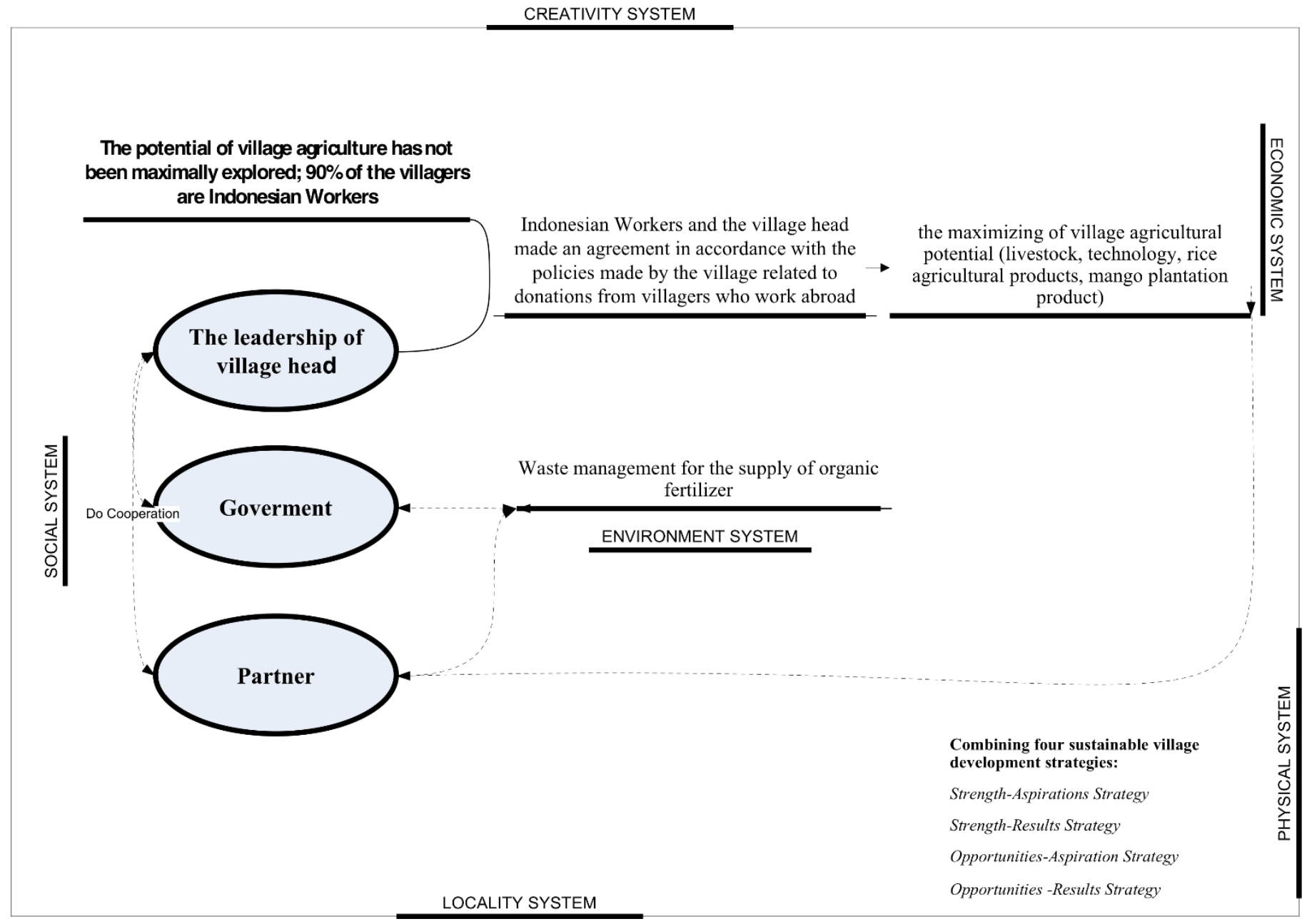

Figure 3. The combination of Majasari village development management principles with the village development strategy as a new strategy for sustainable village development management

\section{CONCLUSIONS}

Before drawing the conclusions, the researcher will invite the readers to return to the question presented in the introductory part: can villages that do not maximize the potential of agriculture be able to carry out sustainable village development? The answer is yes, they can. But there is a condition: the village head should have a strong leadership and a broad view which reflects in the implementation of development management principles. In addition, based on the 
development experience in Majasari Village, there are 4 (four) strategies of village development that can be universally implemented in villages in all developing countries: first, a strategy that utilizes village power to realize the aspirations of the whole village community; second, a strategy that utilizes village strengths to realize the village mission and vision; third, a strategy that takes advantages of the existing opportunities to realize the aspirations of all rural communities; fourth, a strategy that utilizes the existing opportunities to realize the vision and mission of the village. A new thing related to sustainable development management strategies here is the strategies of implementing the principles of village development management that combine the power of village head leadership with the four village development strategies that pay attention to political, economic, social, technological, environmental, and village legality aspects. Through this new strategy, it can be seen that by the power of the village head leadership, the internal and external potentials of the village can be maximally utilized. However, this study is limited to the experience of villages in Indonesia. In the future, it is hoped that a comparative study of the experiences of village development with other countries will be conducted so that the holistic strategy created can be refined.

\section{ACKNOWLEDGMENT}

The authors wish to thank the Universitas Islam Bandung and Universiti Utara Malaysia for the administration of the study.

\section{REFERENCES}

[1] Scoones, I. (2009). Livelihoods perspectives and rural development livelihoods perspectives and rural development. The Journal of Pasant Studies, 36(1): 171196. https://doi.org/10.1080/03066150902820503

[2] Todaro, M.P., Smith, S.C. (2014). Economic Development Twelfth Edition. www.pearsonhighered.com, accessed on Feb. 19, 2018.

[3] Badan Pusat Statistik. Jumlah Penduduk Miskin, Persentase Penduduk Miskin dan Garis Kemiskinan, 1970-2017.

https://www.bps.go.id/dynamictable/2016/01/18/1119/j umlah-penduduk-miskin-menurut-provinsi-2007-

2018.html, accessed on Jun. 1, 2020.

[4] Kementrian Keuangan Republik Indonesia. Buku Pintar Dana Desa. Buku Pintar Dana Desa, 113. https://www.kemenkeu.go.id/media/6749/buku-pintardana-desa.pdf, accessed on Jun. 1, 2020.

[5] Jenkins, T.N. (2000). Putting postmodernity into practice: Endogenous development and the role of traditional cultures in the rural development of marginal regions. Ecological Economics, 34(3): 301-313. https://doi.org/10.1016/S0921-8009(00)00191-9

[6] Akgün, A.A., Baycan, T., Nijkamp, P. (2015). Rethinking on sustainable rural development. European Planning Studies, 23(4): 678-692. https://doi.org/10.1080/09654313.2014.945813

[7] Tomashuk, I. (2017). Problems and prospects of management of rural development. Baltic Journal of Economic Studies, 3(5): 214-220. https://doi.org/10.30525/2256-0742/2017-3-5-214-220

[8] Koopmans, M.E., Rogge, E., Mettepenningen, E., Knickel, K., Šūmane, S. (2018). The role of multi-actor governance in aligning farm modernization and sustainable rural development. Journal of Rural Studies, 59:

252-262.

https://doi.org/10.1016/j.jrurstud.2017.03.012

[9] Courtney, P., Hill, G., Roberts, D. (2006). The role of natural heritage in rural development: An analysis of economic linkages in Scotland. Journal of Rural Studies, 22(4): https://doi.org/10.1016/j.jrurstud.2006.02.003

[10] Popescu, D.L. (2014). Subsistence/semi-subsistence agricultural exploitations: Their roles and dynamics within rural economy/rural sustainable development in Romania. Procedia Economics and Finance, 16: 563-567. https://doi.org/10.1016/s2212-5671(14)00840-5

[11] Chen, C., LeGates, R., Fang, C. (2019). From coordinated to integrated urban and rural development in China's megacity regions. Journal of Urban Affairs, 41(2):

150-169. https://doi.org/10.1080/07352166.2017.1413285

[12] Conneely, R., Mahon, M. (2015). Protected geographical indications: Institutional roles in food systems governance and rural development. Geoforum, 60: 14-21 https://doi.org/10.1016/j.geoforum.2015.01.004 